\title{
Phenomenology and carnival production chain
}

\author{
Paloma Oliveira de Carvalho Santos ${ }^{*}$, Ney Madeira, Danielle Cardoso Joia and Fernando da Silva Assumpção
}

${ }^{*}$ Correspondence:

palomacarvalho@yahoo.com Universidade do Estado do Rio de

Janeiro, Rio de Janeiro, Brazil

\section{Abstract}

Maurice Merleau-Ponty sustained the world engages the body consciousness. 50 years after the publication of his "The Visible and the Invisible", a group of teachers and artists enrolled on the theory and practice of the Rio de Janeiro Carnival propose a discussion on the reverberation of his Phenomenology on this field, trying to understand how the ideas of this philosopher spread through brazilian artistic movement Neoconcretism and, from this, to the practice and thinking of Carnival and its production chain.

Keywords: Phenomenology, Carnival, Artisans, Neoconcretism

\section{Background}

In modern art, the evolution has been finding increasingly the creation process, return to it. For the apprehension process of the artwork has become too detached from the creative process. The very participation should be something implicit, the seizure of a process, not a result

\section{[...] Hélio Oiticica, $1969^{1}$}

The book "The Visible and The Invisible" (Merleau-Ponty 1971), first published in French in 1964, is an achievement in itself of the phenomenology of Maurice MerleauPonty, where the writing is gradually constructed as a process shared with the reader. But, in Brazil, many other achievements derived from this work. Is was read by Mario Pedrosa-a brazilian intellectual involved in the Rio de Janeiro artistic field, specially the Grupo Frente, that in the 1950s seeked a new language of concrete art forms. ${ }^{2}$

This article raises the hypothesis that there would be a greater consequence of this intellectual influence over brazilian neoconcrete works, such as Hélio Oiticica's-part of this influence would have spread beyond erudite circles of the visual arts, especially in the carnival of Samba Schools of the city of Rio de Janeiro. The relationship that Oiticica established with the dancers of Mangueira is widely noted as quoted by the artist himself in many ways. ${ }^{3}$

\footnotetext{
${ }^{1}$ In: Oiticica Filho and Vieira (2009, p. 59).

2 Oiticica, when asked which critic might have understood his work: "Mário Pedrosa. All my influence, in the beginning, was Mário and Ferreira Gullar" (Oiticica Filho and Vieira 2009, p. 81).

${ }^{3}$ Oiticica: "In Mangueira, in the lifestyle of the hill, I found my way. Today, the art for me is pure communication, and every activity that I have is an attempt to communicate" (idem, p. 99).
} 
We are considering that not only the art of the samba schools influenced Hélio Oiticica, but also, his concept of art may have changed the way the carnival artists saw their art from then on. Inside the Samba Schools, some elements of discussion of the art world may have disseminated, originated by the art critic Mario Pedrosa, reaching the so-called "academics" of carnival pioneers.

Such "carnavalescos" (samba school artistic directors) would have motivated to disseminate the concept of innovation or artistry and authorship (represented in their figure of a creator-in-chief) in the Rio de Janeiro carnival unique parade structure, that has put the individuals inside such huge amount of stimulus, that challenges our everyday system of cognition.

If the dissemination of some ideas derived from this philosophy didn't change the carnival itself, at least, among many others cultural influences, it may have helped to change the way its dynamics is today socially valued, from a simple popular cathartic chaos to a complex system of self organization. Today, the Rio de Janeiro carnival is recognized both for preserving the tradition and promoting the expectation of new, notably in the figure of the carnavalesco, as Joãosinho Trinta or, most recently, Paulo Barros and many others. That is a unique sense given for a popular festival, and globally verified.

We hope this article would help engineers to see industrial patterns in unorthodox places, observing how some historical aspects of the Rio de Janeiro Samba Schools complex industrial delivery system has changed, so that today the public itself (local and global) expects the carnival and the parades of the samba schools of Rio de Janeiro to present innovations and original creations, both in relation to its language, as with its technique.

\section{The Rio de Janeiro samba schools carnival production chain}

Today, during their creative process, the carnavalescos and their staffs aim for research of new techniques and materials. Novelties like laser beams on the floats and LED lights on the costumes, thus transformed the carnival production chain, to increasingly include professionals specialized in areas at first not associated with a popular party, but the technology used by experts in special effects (in film or in other performing arts and entertainment events such as mega events and music shows).

Those changes in the carnival production chain appear on the type and amount of technological materials used for the production of costumes and floats, especially from the 1990s on, when the carnavalesco Renato Lage introduced floats with its own lighting systems and neon lights.

Moreover, today, the samba schools also use their parades as an advertising space: plots determined by sponsors (as companies, branding teams of cities or personalities), and the decision to use technological innovations, often imported from other countries, as a way to produce news and excel in the media. As we see in this news by Rafael Galdo for the website G1 (globo.com): "Schools combine technology and parades and enshrine the era of high-tech carnival: Portela had drones, an eagle who bends down and paratroopers. Salgueiro and Mocidade used LED screens in their shows." Recently, Paulo Barros was the one most carnival directors associated with this trend of incorporating methods and materials used in shows, and Broadway musicals (Fig. 1). 


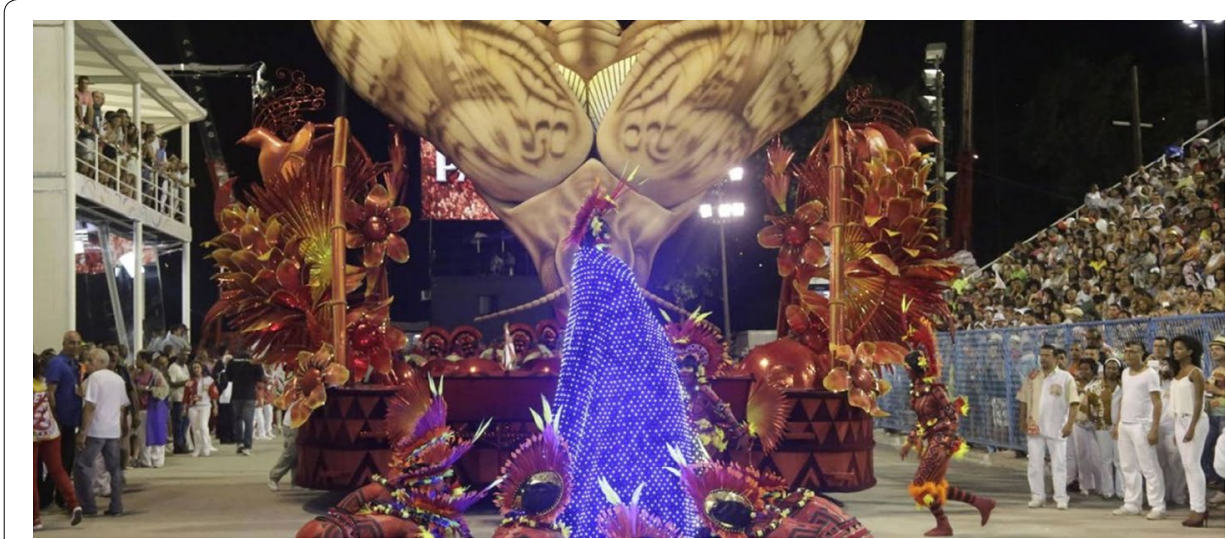

Fig. 1 LEDs make up the mantle of Our Lady of the front commission of Salgueiro. Carnavalescos: Renato Lage and Marcia Lage. Coreographer: Helium Bejani Source: Nina Lima/Agency O Globo. by Rafael Galdo $02 / 16 / 2015$

Recently, specially in the last ten years, however, we have realized another conceptual influence on Carnival: it is seen that the carnival supply chain has tried to appropriate the latest design concepts, recognizing innovation also in the use of sustainable materials. An example of this new mindset is the winner front of the last carnival (2015), the Samba School Beija Flor de Nilópolis that, through the work of costume designer Ney Madeira, presented costumes with craft materials and techniques, giving great importance to visuality (Fig. 2).

Those changes arose from a common modernist context of break with tradition that produced different answers to related topics. The Rio de Janeiro Carnival Samba Schools have accompanied a change of philosophical paradigm, having in common with

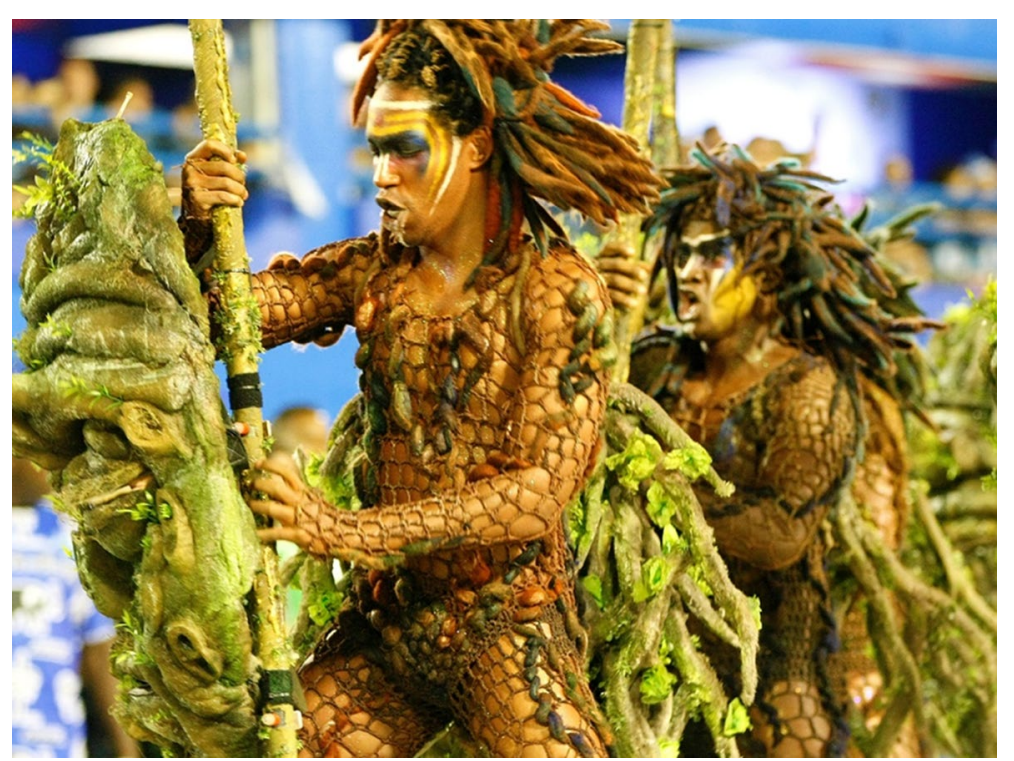

Fig. 2 17.fev.2015 - winner front of the last carnival (2015), the samba school Beija Flor de Nilópolis. photo: Marcelo de Jesus/UOL 
certain artists new concepts about ways to use the space and the body as artistic creation elements.

Specifically Hélio Oiticica attended the Mangueira community and originated works like Parangolés coauthored with samba personalities like the dancer (passista) Nildo da Mangueira. In the Carnival (a performative and ephemeral art), these transformations of philosophical paradigms materialize a new sense of body, correlate to Merleau-Ponty's flesh of the world, acting in new forms of interaction with the environment. Oiticica: "[...] the truth is, dance, rhythm are the own plastic act in is rawness. Essentially this then pointed the direction for the discovery of immanence"[...] (Oiticica Filho 1986, p. 73). In the carnival parade at the Sambadrome, we experience the collectivity; the dance is possible only if the individuality is overcome. Also the understanding of space is determined by experience. We find in Oiticica's writings quotations to Goethe and Nietzsche, regarding the romantic power of ritual, of the popular culture. But specifically the understanding of the body as a tool to a new Ambiental art is what we find related to MerleauPonty Phenomenology.

Theories of Art: Since the 1930s, the critic Mario Pedrosa experimented many different concepts of art, defying academic aesthetic assumptions that reached wide political scope in dialogue with other relevant personalities. From the recognition of the art of the children (together with the Children School of Art-Escolinha de Arte do Brasilprofessor and painter Ivan Serpa), of the mentally ill (together with Dr. Nise da Silveira, a relevant Jungian psychiatrist) or of the natives', for Mr. Pedrosa, "the art was way too important to be confined to a privileged domain of professionals" (D' Angelo 2011, p. 47). This resonates with the experimentation of space led by the Neoconcrete artists, such as Oiticica's concept of anti-art and Ambiental art, and also the dematerialization of art in the idea of "non-object" by the concrete poet and critic Ferreira Gullar (himself an artist who participated and leaded the formulation of the neoconcrete manifesto and exhibitions). In the non-object theory (1960), he quotes directly the great influence the readings of phenomenology in this historical context:

"The term non-object is not intended to designate a negative object or anything that is the opposite of material objects with properties exactly contrary these objects. The non-object is not an antiobject but a special object where is to be performed the synthesis of sensory and mental experiences: a transparent body to phenomenological knowledge, fully visible, which gives itself to the perception leaving no remains. A neat appearance." (Gullar 1999, p. 289)

In 1966, Pedrosa directly relates this concept of Installation or "Ambiental Art" (which derives but also overcome the Dadaist, duchampian idea of anti-art) to Oiticica's coexistence with the samba artists:

"It was during the initiation to the samba that the artist went from the visual experience in its purity, to an experience of tact, movement, sensual fruition of materials, in which the entire body, before restricted by the distant aristocracy of the visual, enters as a total source of sensoriality." (idem, p. 99)

Oiticica himself theorizes this interaction with the samba milieu, about his works called "Parangolés", wearable works of art created since 1964: 
"this is an experience to be done in collective contexts each time wider, without prior preparation of what to do or get certain result. It is therefore most certain the affirmation of Pedrosa when he says that the cultured man is absorbed by the world of images and information, it is only a manipulator of images and no more a creator of models: the model now, each one creates its second their aspirations and desires. In this manifestation appeared the first works created by non-artists: a group of girls from Estacio [another samba school] made clothes with cloth and model by them invented and chosen with which they dressed themselves. Something amazing happened: the fashion, the bad or good taste, do not exist-everything depends on the free, spontaneous invention. The day will come that each person will make their own clothes according to their perception and will, according to their aspiration [...]" (Oiticica Filho and Vieira 2009, p. 53-54).

So, space and body -how the body relates to the space- is the source for a new way of dealing with the world, to break up, overcome dualisms and separations. As Pedrosa writes about Oiticica: "Environmental Art is how Oiticica called his art. In fact is not anything else. In it, nothing is isolated [...]" (idem, p. 98). It means an openness aimed by a generation of thinkers and artists, dealing here with what we are considering "the visibility of the body as a fundamental piece for an openness of perception" and, therefore, of philosophical experience of the world. Oiticica's works resemble carnival costumes in its symbolic, often disturbing forms and the work being made acquires metaphorical strength, as for the british critic Guy Brett:

"the metaphorical meaning of Capas Parangolés also deepens, and they become very different, different materials seem to spring directly as eloquent appendages of the body. Reflecting the exaltations and the problems of the Mangueira [favela], some Parangolés are light and airy (For example, the one bearing the legend 'I am possessed' in a long flag), others are ascetic and heavy as the one that refers to hunger, hanging on the shoulders by means of ropes, heavy dried pet food bags. (Brett 2005, p. 36)

All those artistic experiences relate to a new way of dealing with the body in motion, but also with materials, both hierarchically considered minor forms, that the empiricist philosophy named as secondary qualities those which were not considered interesting (like Color, fattura).

So, we see that science privileged the objective (mass, height) qualities over the secondary qualities. However, art uses those secondary qualities to reach a truth through experience, disregarding this hierarchy of the senses. The multi interpretation of the characteristics of materials, use of colors, the experience of the work in unity cause a "vision" of art that is what keeps arousing interest in objects: the inexhaustible aspect of the work of art, the multiplicity of experiences with the same. Thus, there would not be a whole truth, instead, as you walk and everything is transformed.

The profusion of colors and materials deepen this question: they cause indefinable emotions, being a result of the relationship of the object with oneself. We will always need the experience to understand emotions that cannot be reduced to concepts. Perception therefore is relative and not absolute. We will never know if the tone I see is the same as other people see. 
So, it means that each of us has a complete different perception of the world? No. In the world there is a certain amount of generality, which is what allows communication and standardization that enables social interaction. But these standards are not definitive as we think: there is a limit to the generality. We can always see things in a way a little different. Wealth is the endless task of seeing more and more of what you see... We are interdependent, and our relationship with the world is constantly changing. To notice is being noticed; to touch is being touched. We are the vision of the response that the world has of us. This nearly completes a circle. To see ourselves seeing is not possible, but it's like this illusion (that borders on fantasy) was necessary to restore the intensity of the contact with the world.

\section{The visible and the invisible and the Rio de Janeiro samba schools' creative process}

Phenomenology: where we consider the senses in a way opposed to the Cartesian tradition of abstract thinking. For Merleau-Ponty, the world itself is the remnant, what is lacking in reflection, the blind spot, the unthought... the residue is what interests Merleau-Ponty. For him, we will be naive if we do not consider the blind spot of reflection, believing we are able to find a single truth to the world.

The carnival, in itself, is an experience irreducible to concepts. Although there is the authorial figure of the carnavalesco (director), in the complexity of a show with so many variables and which takes place only once is what redevelops the carnival as a popular party: each member is actually responsible for the outcome of the show together.

It is noticed that the leaders and the Samba schools team leaders relativize the competition, aware that the show needs a general quality level, and that when it happens to a school to perform much better than the other, it is noted a general loss event. That is, the total of the show set has a multiplicity value, transforming this popular presentation in the manifestation of what is most alive, unusual, imponderable.

Merleau-Ponty wants to investigate the world, the source of everything, in his inexhaustible character, in perpetual motion. The resumption process tends to avoid the arrogance of being taken by the logos: to think about is to risk.

The realization of this phenomenology is the process valued in itself. As in the carnival: the creation occurs dynamically today being an industry that requires professionals with an exceptional ability for intuition and improvisation.

As occurs in other creative processes involving large structures (performing arts, movies, architecture, etc.), the Rio de Janeiro Samba Schools creative processes are basically divided in two phases: the early stage of the project (pre-production) and the realization, that is also a design process.

The projective action occurs when the carnival director -carnavalesco- designs the plot and first imagines how the Samba School will develop the Marques de Sapucaí Avenue. Often, at the end of a parade, he is already imagining the plot for the next year, because many times the plot is related to a sponsorship, and the final decision occurs usually along with the definition of budget (sponsorship) during March or April.

By July, the carnival director already has the show designed to be approved by a committee of directors. But, contrary to what occurs in a ballet or opera, it is the visuality which determines the music: the music succeeds the choice of the plot when the carnivalesque establishes a range of issues that have to be told in the samba lyrics, topics 
which are necessary for the theme to work as the basis for the narrative and allegorical line in the parade.

In the following months, the project will undergo many changes. At this phase, the "creativity" happens in the making, when the professionals work with absolute dedication, getting countless sleepless nights. A process that only ends when the school enters the avenue. So, the initial project designed by the carnival is constantly being reinterpreted by numerous performers, especially team leaders (as costume designers and architects, who will perform the floats). In the photos below, we are able to compare and recognize differences between a prototype, undergone to approval, and the final version of the costume, brought to the avenue. These performers will interpret the original guidelines, facing challenges, as adequacy of funding, lack of material... substantial changes and challenges and even personal demands, such as stars and highlights that opine on their costumes (Fig. 3).

That is, the creative process only ends when the school enters the avenue, the floats are getting ready, being pushed... finally everything work as a whole, gets volume and vital energy with merrymakers. What the carnival director once conceived is finally materialized, modifying the original balance of strengths: all the performatic, visual and musical stimulus.

The process takes place in continuous motion, because it only ends on the body of each merrymaker, complemented with the make up. It is comparable to what happens in a movie set, until the last second each detail is important.

Such is the dedication required, that what is make can be hardly classified as work. Professionalism is as important as the emotional engagement, involving community and religious values comparable to what happens with soccer teams: it involves faith.

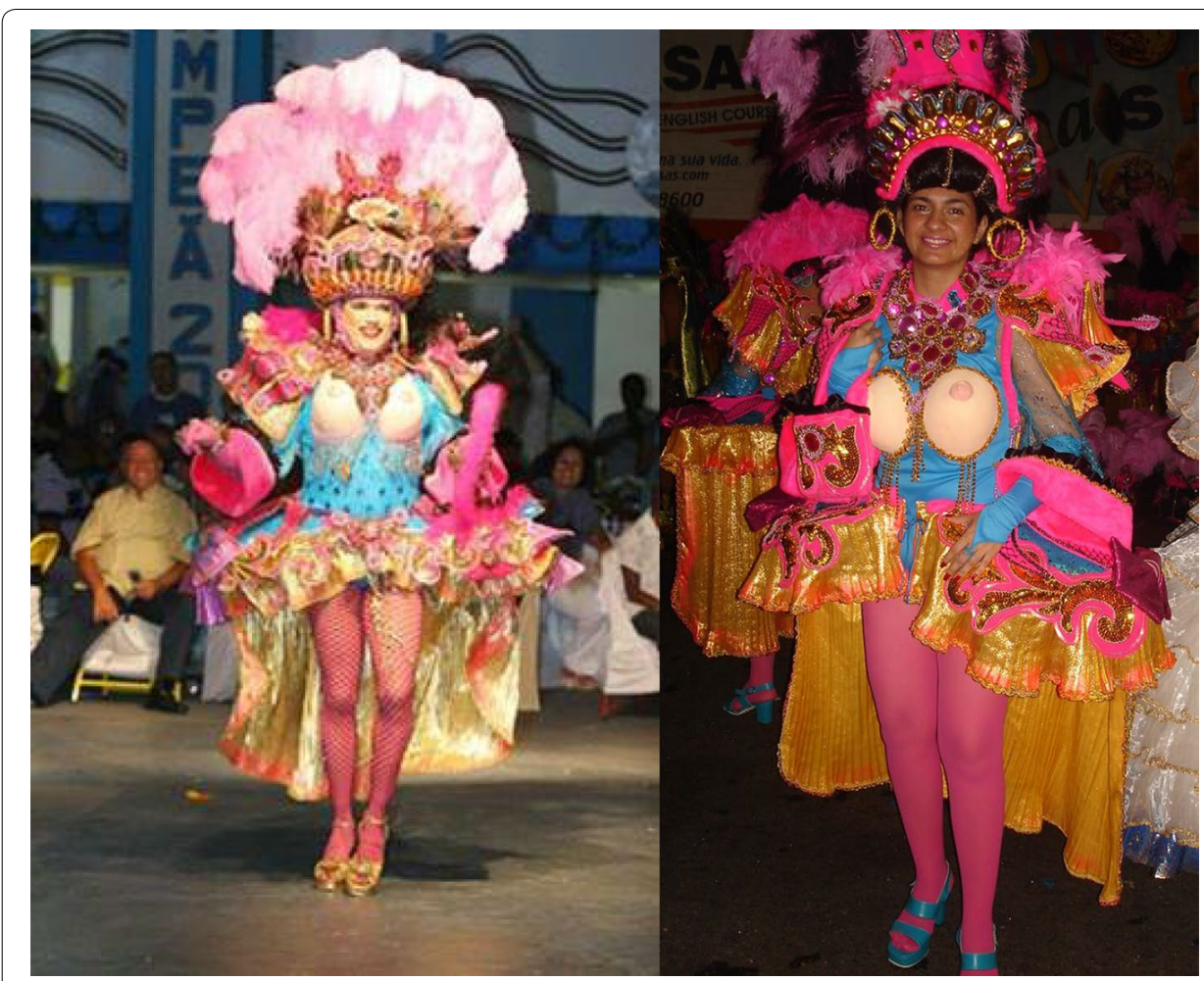

Fig. 3 A costume in two versions: prototype and final. Photo: Samuel Abrantes archive 


\section{The body operationalizing the perceptual faith}

The sensible world is already an abstraction for the philosophical tradition that intellectualized the perception. From Plato to Descartes and Kant, our society has established the division between two worlds: the sensible and the intelligible. The sensible was put under suspiction, but in fact the relationship with the world is the source of all ideas. Merleau-Ponty argued that the modern philosophy hardly sees the world, does not have the perceptual faith.

Further, for Merleau-Ponty, the world is the source of truth. The existence of the world is not questioned, but taken: there is not such thing as an outside the world. Because the truths are based on this perceptual faith, we cannot say they are not true. We cannot prove the existence of the world, we share a faith. So, the relationship with the world is one of interdependence (interwining, chiasm), and the involvement, prior to the modern dicothomy "subject-object".

Merleau-Ponty says that the common man needs the perceptive faith to live, to move around, to communicate, even to socialize. However, our eyes are no longer pure. We look and think, conceptualize all the time. But to experience works of art, we must recognize that our body is wiser than ourselves, that our body is in permanent contact with the world. All this must have got very clear to Hélio Oiticica once he got in touch with the spontaneity of the samba dance and music in the Mangueira samba School, where, by that time (1970s) its participants had a space for creation less influenced by modern occidental paradigms.

Theses, tradition, end up preventing the direct experience with the world. The thought, in fact is in the experience, not in a later stage. We enter the world guiltless to all theses, this would be the premise for the origin of new knowledge: a sincere relationship with the world; to try a pre predicative world, prior to culture. We cannot separate the concept from the experience. The thought modify things, and we must consider that weight. Merleau-Ponty does not believe into the definitive acess to the thing in itself; You do not want to end up with the difficulties of relationship with the world, but take them into account and consider the incompleteness of thought.

The Being is a continuum that does not end, this is its wealth; we can only pursue it in motion sensing. Merleau-Ponty criticizes the notion of the world as passivity, the separation between subject and object, he wants to leave the dichotomy.

The body, as something foreign (a sentinel) is a part of the world. The relationship of the self with the body: they are strangers. They are not as separate as in Descartes, but Merleau-Ponty wants to overcome the separation mind/body. Merleau Ponty: "The body is the part of the world which is closer to me." My body is where there is an opening to the world in a two-way movement.

The Carnival dynamism allows us to realize the work with the whole body: we are impregnated with colors and sound by large-scale event, felt by all senses together.

We live in a perspectival world where there is no absolute vision: prospects conceal and reveal. The invisible can be seen because it is present in the chiasm and the visible can be hidden in the prospects.

In the sambadrome at the Marques de Sapucaí Avenue, the viewer has a frontal point of view lined in sequence, which reinforces an Aristotelian narrative, with a beginning, middle and end. However, the samba has a circular structure, being a musical genre of 
ritual origin; also, for the parading (who is inside the crowd), the perception of time is that of the duration: because everything occurs with such intensity, that is the unanimous declaration of the revelers: "I have not not seen the time go". In this case, each position of the participant, each time he changes the perception of the whole. There is no unitary vision: there are so many things happening at once, that perhaps perception is necessarily phenomenological.

Eliminating the perception acquired the painting straightforwardness, it is evident to seize a thing altogether (frontally) is to take its depth, is a representation: an intellectualization contrary to the experience. So, we could say the Carnival is an event, designed for a specific space contrary to the notion of frame, called theatricality (determined by the front space of the Italian stage).

A deeper evaluation of the phenomenological roots of the neoconcretist art was developed by the art critic Ronaldo Brito. In his view,

"By opting for the expressive character of art, the Neoconcretists removed themselves from the functionalist axis, around which the Constructivist tendencies revolved. And yet, by still siding with them, they retained a certain oblique connection. This is evident in the very productions of the group: in Hélio Oiticica Utópicos (Utopian Reliefs)-speculative topological studies with no immediate practical applicability; in the schemes of penetration and rupture by Amilcar de Castro's system; in the phenomenological and anti-positivistic organic character of Lygia clark's Bichos (Creatures); in the surgical exploration of the parts of the object brought about by Willys de Castro's Objetos Ativos (Active Objects); and in the libidinal impregnation of spaces by Franz Weissmann. It is also evident in the research of color by Aluisio Carvão, Hélio Oiticica and Hércules Barsotti-a banished element in the concretist work, probably because of the impossibility of a more objective formalization.

In all of these works there is something that does not allow itself to be reduced to a simple formal character. There is something that results from a process one could call speculative, which does not adjust itself to the scheme of 'superior design' proposed by Concretism [...] "(Osorio and Kudielka 2010, p. 242)

Ronaldo Brito stresses some topics where this phenomenological aspect changes the perception. We found two of them to be very important in the carnival too. First, time is no longer mechanical, becomes duration, as in a bergsonian view. Second, space becomes a field, an opportunity for event, as the current sambadrome avenue becomes a ritualistic happening.

Those aspects were also being investigated abroad by other artists, as minimalist sculptures developing site specific installations and performers, but specifically the way Oiticica validated and found a deep, existential expression learning from the carnival ritualistic parade and samba lifestyle seems quite unique and to be a permanent achievement in the understanding of the carnival as an artistic expression, working together with all the other traditional meanings. 


\section{Conclusion: non hierarchical relationships; new perspectives}

Perception considers the depth; the Being is inexhaustible because it is the relationship in itself, in its complexity. But the relationships can be enhanced, we can have more acute visions, taking into account the weight of our imagination. We experience the difference of the other, and it's their incompleteness that prevent them being exhaustible. Therefore, man is part of the world as a whole; we see the man is part of the world's flesh without hierarchical points. Then, different points of view might even be nonhumans, including the nature or other people.

The sensible is our mediation with the world, the common structure. For MerleauPonty, openness to the world is the way to ascend to things in itselves, not the renewed traditions, and to operate with the world, not images. Seeking a new source of truth, Merleau-Ponty relates to the whole history of philosophy, but we can see a strong dialogue with Descartes and even Plato. Somehow the Greeks idealized form, creating the concept of ideal as simplification, generalization, reduction, impoverishing the basics, the simple life to the ideal. And this became a deeply rooted tradition, which became european and still is very strong in Brazil.

However, we propose here that the carnival might go against Platonic tradition of transmission of thought, knowledge, through artistic production. The greatest difficulty is the expectation created in the viewer: the tradition leads us in the appreciation of the work with pre ideas; an idealistic and rationalistic reading. We can see how the carnival radicalizes experience, and how the neoconcrete artists and many critics as Mario Pedrosa and Ferreira Gullar were influent to change a social paradigm, as many other artists, from the music, theatre, movies, etc.

In order to cherish our openness to the world, in this article we aimed to show how artists were able to find a in a vital popular cultural expression innovative forms of non hierarchical relational operation, correspondent to a new philosophical perspective that criticizes how the western civilization undermines the body and its dinamic power. So, everything has one or more hidden side. Imaginary projections, fantasy-have significance, are part of $a$ truth... eventually, a good error because there is no such thing as a full understanding.

\section{Authors' contributions}

DCJ and NM are experts on Carnival costume designs and conducted practical researches and NM has won the quoted prizes. FSA and POCS are art historians with philosophical backgrounds and contributed evaluating the cultural consequences of the Rio de Janeiro Carnival evolution. POCS hereby certify to have participated and take full public responsibility for the content in the article "Phenomenology and Carnival production Chain", and that among all, the work is a product of the intellectual environment of the whole team who have worked extensively together. I hereby certify to have participated in the concept, design, analysis, writing, translation and revision of the manuscript. Furthermore, I certify that this material is original, based on the authors' personal research and professional experience. All authors read and approved the final manuscript.

Competing interests

All authors declare that they have no competing interests.

\section{Publisher's Note}

Springer Nature remains neutral with regard to jurisdictional claims in published maps and institutional affiliations. 


\section{References}

Brett G, Maciel K (2005) Brasil experimental. Editora Contracapa, Rio de Janeiro

Globo O (2015). http://oglobo.globo.com/rio/carnaval/2015/

com-leds-comissao-de-frente-do-salgueiro-arranca-aplausos-no-sambodromo-15351582

D’Angelo M (2011) Educaçnao Estética e Crítica de Arte na Obra de Mário Pedrosa. Rio de janeiro, Editora Nau

Gullar F (1999) Etapas da Arte Contemporânea. Editora Revan, Rio de Janeiro

Merleau-Ponty M (1971) O visível e o invisível. Editora Perspectiva, São Paulo

Oiticica Filho H (1986) Aspiro ao Grande Labirinto. Editora Rocco, Rio de Janeiro

Oiticica Filho C, Vieira I (2009) Encontros—Hélio Oiticica. Editora Beco do Azougue, Rio de Janeiro

Osorio LC, Kudielka R (2010) Das Verlangen nach Form—Neoconcretismo und Zeitgenossiche Kunst aus Brasilien. Akademie der Kunste, Berlin

\section{Submit your manuscript to a SpringerOpen ${ }^{\circ}$} journal and benefit from:

- Convenient online submission

- Rigorous peer review

- Open access: articles freely available online

- High visibility within the field

- Retaining the copyright to your article

Submit your next manuscript at $\boldsymbol{\nabla}$ springeropen.com 